\title{
Confirmation of deposit, but confirmation of what?
}

At the 2002 Bacteriology and Applied Microbiology Congress of the International Union of

Microbiological Societies in Paris, the principle of a 'confirmation of deposit' was introduced during discussions. The concept was discussed at the IUMS Congress in Paris 2000 in the circles of the editorial board of the IJSEM, the International Committee on Systematics of Prokaryotes and its Judicial Commission (De Vos et al., 2005). While a good idea in principle, and meant to combat a growing problem with confirmation of the accession numbers of novel strains deposited in collections, no concrete suggestions appear to have been made and some initial discussions/exchanges between a number of curators were held via the Internet in the months following that Congress. However, some of the problems that this concept may have set out to solve remain, and there is clearly some degree of uncertainty about exactly what the requirements should be. The purpose of this document is to use the wording of the Bacteriological Code (the Code) (Lapage et al., 1992), together with changes accepted by the International Committee on Systematics of Prokaryotes (ICSP) (De Vos \& Trüper, 2000, Saddler, 2005; De Vos et al., 2005, Labeda, 2000; Tindall et al., 2008; Labeda \& Oren, 2008), to clarify what is required for confirmation of the deposit of type material in culture collections.

The key wording within the Code and the revisions accepted by the ICSP relates to the deposit of biological material in appropriate culture collections, and is covered by Rules 27 and 30 .

The critical part of Rule 27 states:

'A name of a new taxon, or a new combination for an existing taxon, is not validly published unless the following criteria are met.'
Among the criteria are:

'3) The type is designated for a new taxon, or cited for a new combination, in the IJSEM/IJSB. The type of the taxon must be designated (see Rule 16). In the case of species or subspecies (including new combinations) the type strains must be deposited according to Rule 30.'

\section{Under Note 1:}

'If the initial proposal of the new name or new combination is not effectively published in the IJSEM/ IJSB, valid publication (announcement in a Validation List) of the name in the IJSEM/IJSB is primarily the responsibility of the author of the name or combination together with the requirements of Rule 27(2) and (3) above. However, other individuals may also submit a new name or new combination for valid publication provided it conforms to the Rules of this Code.'

\section{Under Rule 30(3a):}

'As of 1 January 2001 the description of a new species, or new combinations previously represented by viable cultures must include the designation of a type strain, and a viable culture of that strain must be deposited in at least two publicly accessible service collections in different countries from which subcultures must be available. The designations allotted to the strain by the culture collections should be quoted in the published description. Evidence must be presented that the cultures are present, viable, and available at the time of publication.'

Changes to these Rules now helps to clarify the fact that the Code requires that evidence is to be presented confirming that cultures of the type strain are present, viable and available at the time of publication. It should be emphasized that Rule 30(3a) specif- ically relates to the deposit of a type strain of a species or subspecies, and it should be evident that it is that strain and not any other strain that concerns the Code. A direct consequence is the fact that a strain that corresponds to the type strain described in the appropriate publication is present in the collection. It would seem evident that, when a strain is accepted for deposit, it is possible to confirm that it is indeed the type strain. Discussions with a number of curators from a number of different collections have indicated that $5-10 \%$ of all new accessions are problematic. This includes contaminated strains, incorrect strains being sent and problems with the viability of the strains, etc. A second point worth emphasizing is that the new wording applies not only to new species and subspecies but also to new combinations represented by type strains. This would mean that, if the type strain of a species listed on the Approved Lists of Bacterial Names (Skerman et al., 1980, 1989) is held in a single culture collection and that species is transferred to another genus, the type strain must be deposited in a second collection in a different country in order for the new combination to be validly published.

Another point that causes confusion is the use of the term 'certificate of deposit', a concept that has developed in parallel with the concept of 'confirmation of deposit'. However, the key issue is that the requirements of deposit of type strains be confirmed and, while it is helpful to have some kind of formal document, the most important point is that one can clearly identify the collection in question as the source of the documentation. Discussions have always centred on 'confirmation' and not on a 'certificate'.

The concept of 'confirmation of deposit' was initially discussed in connection with the difficulty in 
confirming that the type strain of a new species or subspecies mentioned in a manuscript was, indeed, deposited in a culture collection, because the numbers allocated by the collection were not made public until after publication of the article.

Consequently, 'confirmation of deposit' primarily relates to strains held in collections where there is no other means of confirming that the collection number has been allocated to that organism. In the case of those collections with an Internet presence, strain information on holdings that are already publicly available may make it possible to confirm that the strain has already been deposited and is listed in the online catalogue. In cases where the collection neither has an Internet presence nor publishes a catalogue, or where strains are held confidentially until after publication of the manuscript, the only way of determining that a type strain has been deposited according to the Rules of the Code is via documentation by the collections. It is the policy of the World Federation of Culture Collections, as well as other regional culture collection organizations/federations, to encourage and be of assistance to member collections that wish to publish collection catalogues, either in print form or via the Internet.

In order to help authors, editors, reviewers and collections to conform to the current Rules of the Code, the following list of requirements should be helpful:

(i) the 'confirmation of deposit' applies to the deposit of all type strains of new species and subspecies, as well as new combinations, where it is otherwise impossible to determine that the strain in question has been allocated a particular collection number;

(ii) the collection can confirm that the strain deposited represents the type strain of the taxon in question. Depositors of strains are responsible for making available to the collections all information on the properties of the strain that may be required to fulfil that task; (iii) that the strain is viable, which would include confirmation of the fact the strain has been successfully stored by appropriate methods (freeze drying, liquid drying, freezing, etc.);

(iv) that the strain will be available at the time the publication appears and that the collection number does not apply to a number issued solely for patent purposes or a safe deposit or that other forms of restrictions that would hinder bona fide systematic research have not been imposed;

(v) documentation provided by the collections should clearly identify the collection as the source of that information. The listing of names and collection numbers on delivery slips or invoices is not adequate;

(vi) in order for names to be validly published, the appropriate type strains designated in the manuscript in the IJSEM or published in papers in another journal submitted for inclusion in the Validation Lists must be accompanied by documentation that allows the editors and the ICSP to confirm that the five conditions listed above have been met by two different collections in two different countries. Strain numbers from additional collections that are unable to comply with all these points may also be included, but would not be considered to fulfil the requirements of the Code.

Despite the fact that the requirements listed above centre on the work of the collections, it remains the sole responsibility of the depositor(s) to supply the collections with the type strains well in advance of publication, so that they can complete their work. It is also the sole responsibility of the depositor(s) to make sure that the collections are supplied with authentic type material. It should be remembered that the system described above was introduced to combat a growing number of problems. In many cases, collections are not only verifying the type material held in the collections at the time of accession but are also verifying other data associated with the type material, thus helping to minimize errors in the published literature. In principle, the concept should help to ensure that higher standards are being applied to taxonomic work, enabling the key elements of verifying existing experimental data and expanding on the dataset associated with authentic biological material (type strains) to be carried out. In collections that are currently unable to comply with the requirements listed above, it is hoped that, by explicitly stating what is required of collections holding type material, appropriate staffing and funding will be made available for them to comply.

\section{B. J. Tindall}

DSMZ - Deutsche Sammlung von Mikroorganismen und Zellkulturen $\mathrm{GmbH}$, Inhoffenstrasse 7B, 38124

Braunschweig, Germany

Correspondence: B. J. Tindall (bti@dsmz.de)

De Vos, P. \& Trüper, H. G. (2000). Judicial Commission of the International Committee on Systematic Bacteriology. IXth International (IUMS) Congress of Bacteriology and Applied Microbiology. Minutes of the meetings, 14, 15 and 18 August 1999, Sydney, Australia. Int J Syst Evol Microbiol 50, 2239-2244.

De Vos, P., Trüper, H. G. \& Tindall, B. J. (2005). Judicial Commission of the International Committee on Systematics of Prokaryotes. Xth International (IUMS) Congress of Bacteriology and Applied Microbiology. Minutes of the meetings, 28, 29 and 31 July and 1 August 2002, Paris, France. Int J Syst Evol Microbiol 55, 525-532.

Labeda, D. P. (2000). International Committee on Systematic Bacteriology. IXth International (IUMS) Congress of Bacteriology and Applied Microbiology. Minutes of the meetings, 14 and 17 August 1999, Sydney, Australia. Int J Syst Evol Microbiol 50, 2245-2247.

Labeda, D. P. \& Oren, A. (2008). International Committee on Systematics of Prokaryotes. XIth International (IUMS) Congress of Microbiology and Applied Bacteriology. Minutes of the meetings, 23, 24, 26 and 28 July 2005, San Francisco, CA, USA. Int J Syst Evol Microbiol 58, 1746-1752.

Lapage, S. P., Sneath, P. H. A., Lessel, E. F., Skerman, V. B. D., Seeliger, H. P. R. \& Clark, W. A. (editors) (1992). International Code of Nomenclature of Bacteria (1990 Revision). 
Bacteriological Code. Washington, DC: American Society for Microbiology.

Saddler, G. S. (2005). International Committee on Systematics of Prokaryotes. Xth International (IUMS) Congress of Bacteriology and Applied Microbiology. Minutes of the meetings, 28 and 30 July 2002, Paris, France. Int J Syst Evol Microbiol 55, 533-537.
Skerman, V. B. D., McGowan, V. \& Sneath, P. H. A. (editors) (1980). Approved lists of bacterial names. Int J Syst Bacteriol 30, 225-420.

Skerman, V. B. D., McGowan, V. \& Sneath, P. H. A. (editors) (1989). Approved Lists of Bacterial Names (Amended edition).

Washington, DC: American Society for Microbiology.
Tindall, B. J., De Vos, P. \& Trüper, H. G. (2008). Judicial Commission of the International Committee on Systematics of Prokaryotes. XIth International (IUMS) Congress of Bacteriology and Applied Microbiology. Minutes of the meetings, 23, 24 and 27 July 2005, San Francisco, CA, USA. Int J Syst Evol Microbiol 58, 1737-1745. 